\title{
A seismic-reflection investigation of gas hydrates and sea-floor features of the upper continental slope of the Garden Banks and Green Canyon regions, northern Gulf of Mexico: Report for cruise G1-99-GM (99002)
}

by Alan Cooper $^{1}$, David Twichell ${ }^{2}$, Patrick Hart ${ }^{1}$

Open-File Report 99-570

1999

This report is preliminary and has not been reviewed for conformity with U.S. Geological Survey editorial standards or with the North American Stratigraphic Code. Any use of trade, firm, or product names is for descriptive purposes only and does not imply endorsement by the U.S. Government.

\section{U.S. DEPARTMENT OF THE INTERIOR}

\section{U.S. GEOLOGICAL SURVEY}

\footnotetext{
${ }^{1}$ Menlo Park, California

${ }^{2}$ Woods Hole, Massachusetts
} 


\section{Introduction}

During April 1999, the U.S. Geological Survey (USGS) conducted a 13-day cruise in the Garden Banks and Green Canyon regions of the Gulf of Mexico (Figures 1 and 2). The R/V Gyre, owned by Texas A\&M University, was chartered for the cruise. The general objectives were (1) to acquire very high resolution seismic-reflection data and side-scan sonar images of the upper and middle continental slope (200-1200-m water depths), (2) to study the acoustic character and features of the sea floor for evidence of sea-floor hazards, and (3) to look for evidence of subsurface gas hydrates and their effects.

The Gulf of Mexico is well known for hydrocarbon resources, with emphasis now on frontier deep-water areas. For water depths greater than about $250 \mathrm{~m}$, the pressure-termperature conditions are correct for the development of shallow-subsurface gas hydrate formation (Anderson et al., 1992). Gas hydrates are ice-like mixtures of gas and water (Kvenvolden, 1993). They are known to be present from extensive previous sampling in sea-floor cores and from mound-like features observed on the sea floor in many parts of the northern Gulf, including the Green Canyon and Garden Banks areas (e.g., Roberts, 1995). Seismic-reflection data are extensive in the Gulf of Mexico, but few very-high-resolution data like those needed for gas-hydrate studies exist in the public domain. The occurrence and mechanisms of gas hydrate formation and dissociation are important to understand, because of their perceived economic potential for methane gas, their potential controls on local and regional sea-floor stability, and their possible effects on earth climates due to massive release of methane greenhouse gas into the atmosphere.

Three high-resolution seismic-reflection systems and one side-scan sonar system were used on the cruise to map the surface reflectance and features of the sea floor and the acoustic geometries and character of the shallow sub-surface (Table 1). The cruise was designed to acquire regional and detailed local information. The regional survey covered an area about $3400 \mathrm{~km}^{2}$ in the Green Canyon and Garden Banks regions. Data recorded included $15 \mathrm{cu}$. in. water gun multichannel seismic-reflection and Huntec boomer information. Detailed surveys were planned in two parts of the study area, but due to a winch failure only one detailed survey was done in the Green Canyon area. The detailed survey included collection of $15 \mathrm{cu}$. in. water gun multichannel seismic-reflection, chirp seismic-reflection, and side-scan data.

The regions surveyed include basins and ridges formed by salt movements and characterized by thick surficial, relatively young (Pleistocene and younger) sediments. Swath-bathymetry data (Figure 2) show that the sea floor has extensive sea-floor faults, piercement features, and slumps -- features whose development may be related partly to shallow gases and gas hydrates.

The specific objectives of the cruise were (a) to investigate the distribution and character of potential sea-floor failures (hazards) and their relationship to known and inferred gas hydrate deposits; (b) to image known and suspected gas hydrate features with different seismicreflection systems to look at systematic variations in sub-surface structure in gas hydrate and non-hydrate areas; (c) to outline the shallow structures of the gas hydrate stability zone including shallow water-flow areas, to ascertain the potential impact of gas hydrate 
Figure 2

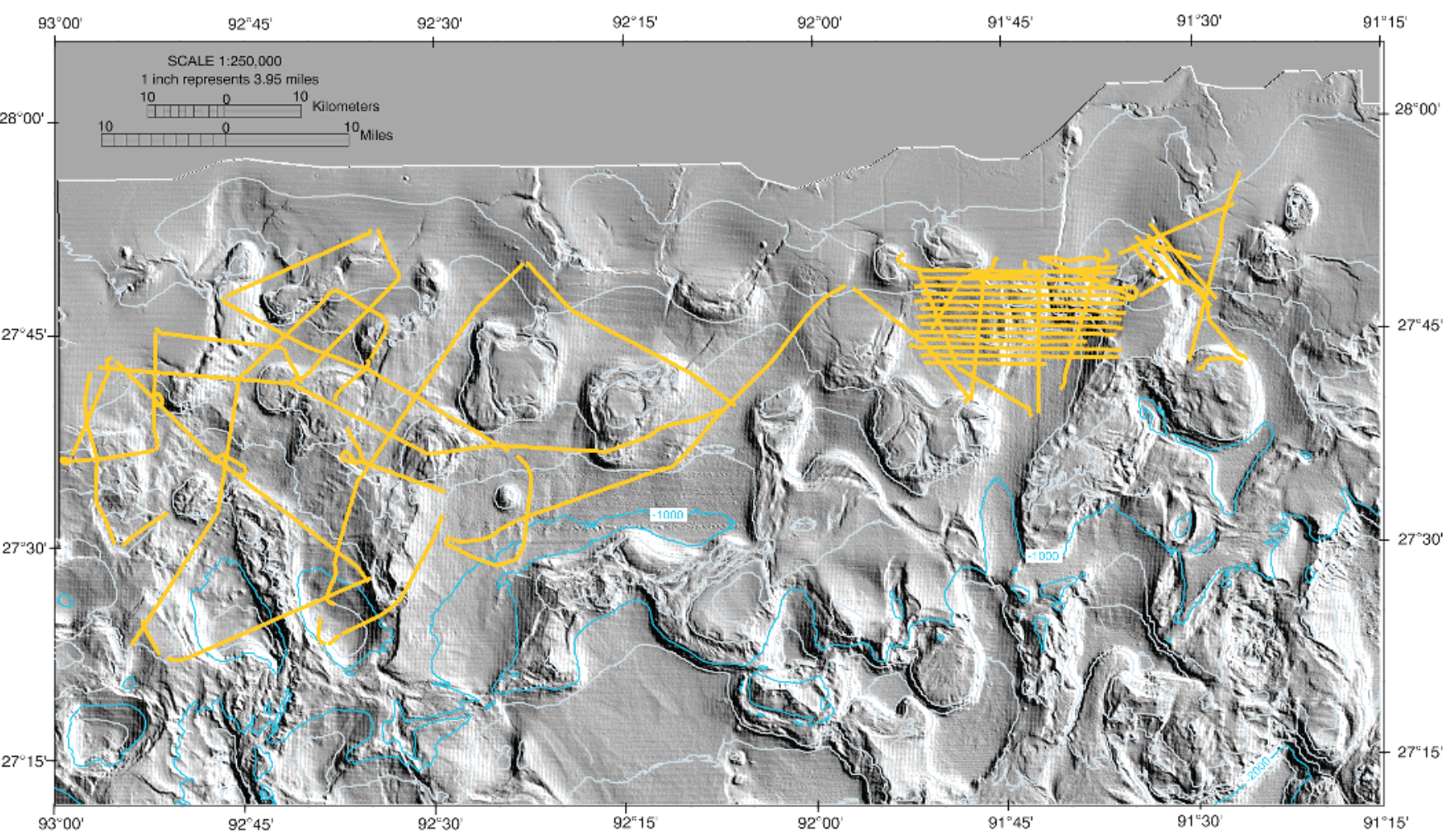

Figure 2. Shaded-relief map of NOAA swath bathymetry data in the study area. Locations of seismic-reflection tracklines for cruise G1-99-GM are also shown. The irregular bathymetry of basins, rises and sea-floor displacements result principally from movements of deep-seated salt. 
formation/distribution on stability of the sea floor. Although seismic data alone cannot be used to identify gas hydrate deposits unequivocally, they are useful in delineating the anomalous subsurface features (e.g., structures, acoustic facies, seismic-attributes, etc.) that are commonly associated with areas where gas hydrates have been recovered in cores.

During the cruise, about $1400 \mathrm{~km}$ of high resolution multichannel and single-channel seismicreflection data and about $500 \mathrm{~km}$ of side-scan and chirp seismic-reflection data were recorded (Figures 1 and 2). The following report describes the field operations and equipment systems employed, gives some examples of ship-board seismic-reflection records, and outlines a few preliminary results.

\section{Cruise science staff}

$\begin{array}{lll}\text { Alan Cooper } & \text { Co-chief scientist, Geophysicist } & \text { USGS-Menlo Park } \\ \text { David Twichell } & \text { Co-chief scientist, Oceanographer } & \text { USGS-Woods Hole } \\ \text { Chris Anton } & \text { Geologist } & \text { USGS-Woods Hole } \\ \text { Jeffrey Brody } & \text { Computer specialist } & \text { USGS-Menlo Park } \\ \text { Bill Danforth } & \text { Geologist } & \text { USGS-Woods Hole } \\ \text { Dave Foster } & \text { Geologist } & \text { USGS-Woods Hole } \\ \text { Patrick Hart } & \text { Geophysicist } & \text { USGS-Menlo Park } \\ \text { Barry Irwin } & \text { Geophysicist } & \text { USGS-Woods Hole } \\ \text { Larry Kooker } & \text { Electronics Technician } & \text { USGS-Menlo Park } \\ \text { David Nichols } & \text { Electronics Technician } & \text { USGS-Woods Hole } \\ \text { Thomas Obrien } & \text { Electronics Technician } & \text { USGS-Woods Hole } \\ \text { Walter Olsen } & \text { Mechanical Technician } & \text { USGS-Menlo Park } \\ \text { Graham Standen } & \text { Huntec deep-tow technician } & \text { GC } \\ \text { Harold Williams } & \text { Mechanical Technician } & \text { USGS-Menlo Park }\end{array}$

Affiliations:

GC: Geoforce Consultants (under contract to USGS)

USGS: U. S. Geological Survey, Menlo Park, CA

\section{Equipment Systems}

The equipment systems used during the cruise are listed in Table 1. All equipment was provided by USGS, with exception of a spare 15 in $^{3}$ water gun that was furnished by University of Mississippi. An operations log showing the amounts of data recorded with these systems is outlined in Table 2. Appendix A gives a detailed list of trackline data collected. Survey speeds ranged from 2.5 to 4.5 knots. Seismic-reflection systems were fired at different energy levels and rates, as noted. The seismic-reflection data were sampled at fast rates (4 $\mathrm{kHz}$ to $33 \mathrm{kHz}$ ) at or near the capacity of the recording systems, to attain the greatest possible resolution of waveforms for later data analysis. With the fast rates, nearly 60 gigabytes of data were recorded during the 8 days of data collection.

Seas were mixed with highly variable wind condtions and seas generally less than 4-6 feet, but operations were halted during a 2-day storm. Data quality is generally good, but is 
affected in various places by noise from several sources: seismic-shooting ships, cross-talk between boomer and water-gun seismic-reflection systems, and nearby drilling operations. Additional information about the data recorded on the cruise, and its public availability can be obtained at the website:

http:/walrus.wr.usgs.gov/docs/infobank/tiger/g/g199gm/html/g-1-99-gm.meta.html

Table 1: Equipment systems used on cruise G1-99-GM (99002)

\begin{tabular}{|c|c|c|}
\hline System & Components & Comments \\
\hline Navigation & $\begin{array}{l}\text { A USGS real-time YONAV system was used for } \\
\text { lab/bridge display of positions and data recording. } \\
\text { Inputs were from a KVH Heading Indicator and a } \\
\text { SATPAK DGPS receiver. }\end{array}$ & $\begin{array}{l}\text { Raster images of NOAA } \\
\text { swath bathymetry were } \\
\text { displayed for real-time } \\
\text { positioning of tracks, to cross } \\
\text { sea-floor features of interest. }\end{array}$ \\
\hline $\begin{array}{l}\text { High- } \\
\text { resolution } \\
\text { multi-channel } \\
\text { seismic- } \\
\text { reflection }\end{array}$ & $\begin{array}{l}\text { MCS data were recorded using a 24-channel ITI } \\
\text { streamer with } 10 \mathrm{~m} \text { groups and } 3 \text { phones per group. The } \\
\text { streamer was towed at an estimated } 1-3 \text { m depths (no } \\
\text { depth sensors on the streamer), and farthest offset } \\
\text { channel was about } 270 \mathrm{~m} \text { behind the source. A } \\
\text { Geometrics STRATAVIEW with marine controller and } \\
2 / 4 \text { gbyte DAT tape drive was used for the digital } \\
\text { recording system. The source was a } 15 \mathrm{in}^{3} \text { water gun } \\
\text { fired by a SureShot gun-timing system. The navigation } \\
\text { system provided gun-shot-triggers on a constant-time } \\
\text { basis. A } 50 \text { scfm Bauer Compressor provided air at a } \\
\text { pressure of about } 2000 \text { psi. }\end{array}$ & $\begin{array}{l}\text { MCS data were sampled at } 4 \\
\mathrm{kHz} \text { rate; and, one trace } \\
\text { displayed aboard ship with a } \\
\text { Printrex thermal plotter, via } \\
\text { the STRATAVIEW marine } \\
\text { controller. Water gun was } \\
\text { fired at } 6 \text { sec. intervals, and } \\
\text { towed about } 1 \mathrm{~m} \text { depth. }\end{array}$ \\
\hline Huntec & $\begin{array}{l}\text { A Huntec system owned by USGS was used, with its } \\
\text { boomer source fired at variable power settings of } 500 \text { - } \\
1000 \text { joules. The systems two receivers were used (a } \\
\text { hydrophone inside of the tow fish and a } 1-\mathrm{m} \text {-long, 3- } \\
\text { element streamer towed behind the fish). Fish tow } \\
\text { depth was about } 150 \mathrm{~m} \text { at a ship speed of } 3.5 \mathrm{kt} \text {. } \\
\text { Seismic signals from the fish were fed through } \\
\text { shipboard amplifier/filters (set to OUT) and then to the } \\
\text { MudSeis recording systems and EPC graphic recorder. }\end{array}$ & $\begin{array}{l}\text { The boomer was fired at } \\
\text { rates of } 0.75-1.25 \mathrm{sec} \text {. } \\
\text { depending on water depth. } \\
\text { Data were recorded at } 32 \\
\mathrm{kHz} \text { sampling rate. For the } \\
\text { last half of the cruise, a } \\
\text { second external streamer was } \\
\text { added in place of the internal } \\
\text { hydrophone. } 60 \mathrm{hz} \text { noise is } \\
\text { common. }\end{array}$ \\
\hline Side Scan & A DataSonics SIS-1000 side-scan fish was used. & $\begin{array}{l}\text { Side scan fired at } 1 \mathrm{sec} \text {. rate } \\
\text { giving a range of } 750 \mathrm{~m} \text { to } \\
\text { each side of the tow fish. }\end{array}$ \\
\hline $\begin{array}{l}\text { Chirp seismic- } \\
\text { reflection }\end{array}$ & $\begin{array}{l}\text { An internal chirp seismic-reflection system in the SIS- } \\
1000 \text { system was used. }\end{array}$ & $\begin{array}{l}\text { Fired at } 1 \text { sec. rate, with side } \\
\text { scan. }\end{array}$ \\
\hline
\end{tabular}


Table 2: Operations log for cruise G1-99-GM (99002)

\begin{tabular}{|l|l|l|l|}
\hline Operation & Time Spent & Data Collected & Comment \\
\hline $\begin{array}{l}\text { Multichannel seismic- } \\
\text { reflection: water gun }\end{array}$ & $\sim 199$ hours & $\begin{array}{l}\sim 1400 \mathrm{~km} \text { along } 68 \\
\text { seismic-reflection } \\
\text { tracklines }\end{array}$ & $\begin{array}{l}15 \mathrm{in}^{3} \text { water gun; done on all } \\
\text { seismic-reflection and side-scan } \\
\text { tracklines. }\end{array}$ \\
\hline $\begin{array}{l}\text { Huntec deep-tow } \\
\text { seismic-reflection } \\
\text { system }\end{array}$ & $\sim 129$ hours* & $\begin{array}{l}\sim 900 \mathrm{~km} \text { along } 44 \\
\text { seismic-reflection } \\
\text { tracklines }\end{array}$ & $\begin{array}{l}\text { Boomer source; not done when chirp } \\
\text { seismic-reflection was used. }\end{array}$ \\
\hline $\begin{array}{l}\text { Chirp seismic-reflection } \\
\text { system }\end{array}$ & $\sim 71$ hours* & $\begin{array}{l}\sim 500 \mathrm{~km} \text { along } 24 \\
\text { seismic-reflection } \\
\text { tracklines }\end{array}$ & $4-10 \mathrm{kHz}$ chirp swept source \\
\hline Side-scan system & $\sim 71$ hours & $\begin{array}{l}\sim 500 \mathrm{~km} \text { along } 24 \text { side- } \\
\text { scan tracklines }\end{array}$ & $100 \mathrm{kHz}$ side-scan \\
\hline Transit & $\sim 49$ hours* & none & To/from operational area \\
\hline Equipment downtime & $\sim 10$ hours* & none & Startup and repairs \\
\hline Weather delay & $\sim 53$ hours* & none & Transit and 23-hour layover \\
\hline TOTAL & 312 hours & & 13 days (total of * items) \\
\hline
\end{tabular}

\section{Onboard Data Processing}

Data from the SIS-1000 and multichannel seismic-reflection systems were partly processed onboard ship during the cruise to facilitate data access and display.

MCS system: SEG-D digital data on magnetic tapes written by the field recording system were reviewed, edited, compiled into complete profiles, and written to tape in SEG-Y format for later processing at the Menlo Park(CA) processing facility.

SIS system: Raw side-scan sonar data from the SIS data were corrected for water travel path and ship's position to created georeferenced images that were used to create a sea-floor mosaic showing sea-floor backscatter. The chirp seismic-reflection profiles were cleaned up, merged with navigation information and plotted in profile format. The navigation and chirp seismicreflection data were combined with other shipboard information (e.g., descriptive text, shipboard photos, etc.) and written to a set of CD-ROMs for later data reference (Foster et al., 1999).

\section{Seismic-reflection Studies}

The seismic-reflection studies (Table 3) were conducted in water depths of 250 to $1200 \mathrm{~m}$, and are in two general categories: 1) those focussing on the subsurface distribution and characterization of gas hydrates and related features of the gas hydrate stability zone and 2) those directed toward acoustic characterization of the sea-floor and the relation of gas hydrates and related features to sea-floor stability and mass-wasting deposits. The three seismicreflection data sets are directed principally to the first objective, and the side-scan and chirp seismic-reflection data sets are focused largely to the second. 
Table 3: Seismic-reflection studies done on cruise G1-99-GM

\begin{tabular}{|l|l|l|}
\hline \multicolumn{1}{|c|}{ Study } & \multicolumn{1}{|c|}{ Area } & \multicolumn{1}{c|}{ Comments } \\
\hline $\begin{array}{l}\text { Structure and stratigraphy of } \\
\text { the upper sedimentary section } \\
\text { and the geometry and extent of } \\
\text { the gas-hydrate stability zone } \\
\text { (GHSZ). }\end{array}$ & $\begin{array}{l}\text { Upper- to middle-continental } \\
\text { slope from about 300 m water } \\
\text { depth (i.e, the approximate depth } \\
\text { of shallowest known gas hydrate } \\
\text { occurrence in the Gulf) to about } \\
1200 \text { m water depth. }\end{array}$ & $\begin{array}{l}\text { Look for seismic-reflection } \\
\text { evidence of gas hydrates, trapped } \\
\text { gases, fluid-flow zones, and } \\
\text { local/regional GHSZ thickness } \\
\text { variations on long profiles across } \\
\text { the continental slope. }\end{array}$ \\
\hline $\begin{array}{l}\text { Acoustic characterization of } \\
\text { the sea floor to identify } \\
\text { possible links between gas } \\
\text { hydrates, sea-floor failures, } \\
\text { mass-wasting deposits and } \\
\text { other sea-floor features (e.g. } \\
\begin{array}{l}\text { authigenic deposits, mud } \\
\text { diapirs) }\end{array}\end{array}$ & $\begin{array}{l}\text { Upper- to middle-continental } \\
\text { slope where steep sea-floor } \\
\text { bathynetric gradients are known, } \\
\text { where fault scarps are common, } \\
\text { and where areas of high } \\
\text { backscatter occur. }\end{array}$ & $\begin{array}{l}\text { Look for regional correlations of } \\
\text { sea-floor features in swath } \\
\text { bathymetry, backscatter, and } \\
\text { near-surface seismic-reflection } \\
\text { data to understand role of gas } \\
\text { hydrates. }\end{array}$ \\
\hline $\begin{array}{l}\text { Possible links between sea- } \\
\text { floor failures, shallow faulting, } \\
\text { intrusive structures and gas } \\
\text { hydrates of the uppermost } \\
\text { sedimentary section. }\end{array}$ & $\begin{array}{l}\text { Areas of apparent sea-floor scarps } \\
\text { and slumps on the continental } \\
\text { slope, based on regional 100-m- } \\
\text { gridded swath bathymetry data. }\end{array}$ & $\begin{array}{l}\text { Attempt to identify the role, if } \\
\text { any, of gas hydrates in surface } \\
\text { and sub-surface failures. }\end{array}$ \\
\hline
\end{tabular}

The following sections briefly describes the field studies (Table 3), and gives a few examples of initial field observations.

\section{Structure and stratigraphy}

Extensive studies on the structure and stratigraphy of the Northern Gulf of Mexico and Green Canyon and Garden Banks regions have been done (e.g., Goodwin and Prior (1989), Weimer et al. (1998)). Yet, few long regional high-resolution multichannel seismic-reflection profiles across the upper- and middle-slope have been published. We recorded many regional profiles to establish the regional seismic character and variability of the shallow Pleistocene and younger sedimentary section that is locally strongly deformed by deep-seated salt structures. The three seismic-reflection systems imaged the sedimentary section at variable vertical and lateral resolutions to a maximum depth of at least the sea-floor multiple reflection. Profile locations were chosen using NOAA swath bathymetry maps, to extend from near the shelf edge down the slope across typical basin and rise features that have locally faulted sea-floors, sometimes with anomalous acoustic features on the sea floor (Figure 3). Some profiles were down the axis of basins, and others crossed the basin flanks and salt diapirs. Profile locations were also chosen to cross sites where shallow-water flows have been reported in drill holes and where sea-floor gas hydrate deposits have been cored or seen from submersibles. 


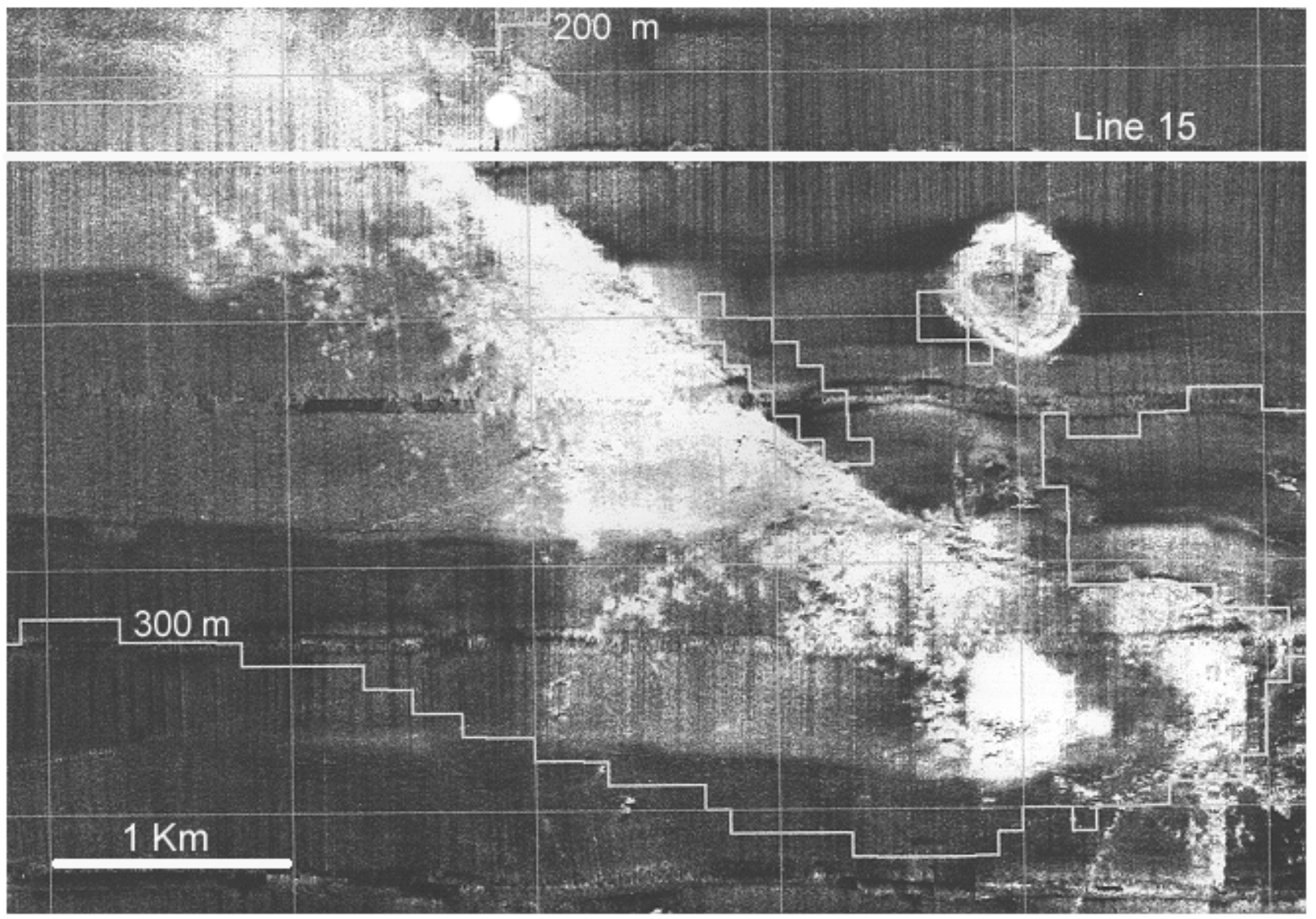

Figure 3. Example of side-scan data recorded on cruise G1-99-GM in the Green Canyon area, shown sea-floor backscatter information. Light colored areas are high backscatter (hard ground) and dark areas are low backscatter (soft ground). High backscatter is associated with sea-floor fault and diapir systems where gases, fluids, sediment rise to the seafloor resulting in likely diagenetic deposits (e.g., authigenic carbonates), gas hydrates (where stable), brines, and coarse or disrupted sediments. Blocky lines show approximate water depths. Solid white line is location of seismic-reflection Line 15 in Figure 4. 
The extent of the gas hydrate stability zone (GHSZ) in the study area is not well known because of potentially large variations in factors that affect hydrate-stability (e.g., water- and subsurface-temperatures, gas concentrations and compositions, pore-water salinities, local over-pressures, etc). A bottom simulating reflection (BSR), found elsewhere at the base of the GHSZ was not observed; however, along many regional profiles the shallowest occurrence of chaotic-seismic-facies zones with high-amplitude reflections (possible shallow gas?) in the upper sedimentary section deepened with increasing water depths -- much like the characteristic behavior of BSRs. The chaotic zones are stratigraphically controlled, and in many cases where they lie close to the base of the estimated GHSZ, seismic amplitudes increase (i.e., possible gas trapped beneath hydrate or stratigraphic horizons?). In areas of complex shallow structure near piercement features, where gas hydrates have been sampled by others, local high-amplitude reflections with cross-cutting geometries are sometimes recorded. These reflections may be from trapped gases or deformation features near the base of GHSZ.

\section{Acoustic characterization}

The acoustic character of the seafloor and upper-sedimentary sections is highly variable. The sea floor ranges from low-backscatter (dark) to very-high back-scatter (light) tones (Figure 3). The seismic signatures at several resolutions range from well-stratified to seismically opaque (Figures 4, 5, and 6). Areas of structural complexity are commonly marked by seismic wipeout zones or by few coherent reflections that also have a high-backscatter signature in the side-scan images. Areas underlying known sea-floor gas hydrates commonly exhibit similar wipe-out zones with some high-amplitude chaotic seismic facies. Over broad basinal and basin-flank areas, the upper sedimentary section is uniformly stratified but laterally deformed in thin horizons (10-50 m thick) that can be traced over large distances, up to tens of kilometers. In these areas, side-scan images show low back-scatter for the sea floor. In some places on the upper slope, the thin deformed horizons may extend up to the seafloor where they outcrop and are marked by areas of high backscatter (Figures 3 and 4). The high backscatter here and across similar sea-floor features on the upper slope is likely hardground possibly including coarse sediment, authigenic carbonates, hydrates, and other debris. On basin floors, the shallow subsurface is marked in many places by chaotic or seismically opaque zones that also have high sea-floor backscatter -- these are likely channel and masswasting deposits.

The profiles across the continental slope also exhibit strong local amplitude variations in the upper sedimentary section. Many factors can cause high-amplitude reflections (e.g., largeimpedance contrasts with interbedded gas, sands, gas hydrates; geometric focusing; etc.). In the shallow subsurface depths, the acoustic facies and geometries of high-amplitude reflections are suggestive of gas accumulations (Figures 5 and 6); however, the polarity of the reflections, expected to be negative from gas deposits, could not be determined in the field data. Large-amplitude variations are also observed (a) in zones along underlying structures, especially on the flanks and crests of ridges, in places where gases and fluids may be advecting along faults and diffusing through the uppermost strata, and (b) where gas hydrates and authigenic deposits are found above shallow diapiric structures of likely mud/sand 
Figure 5

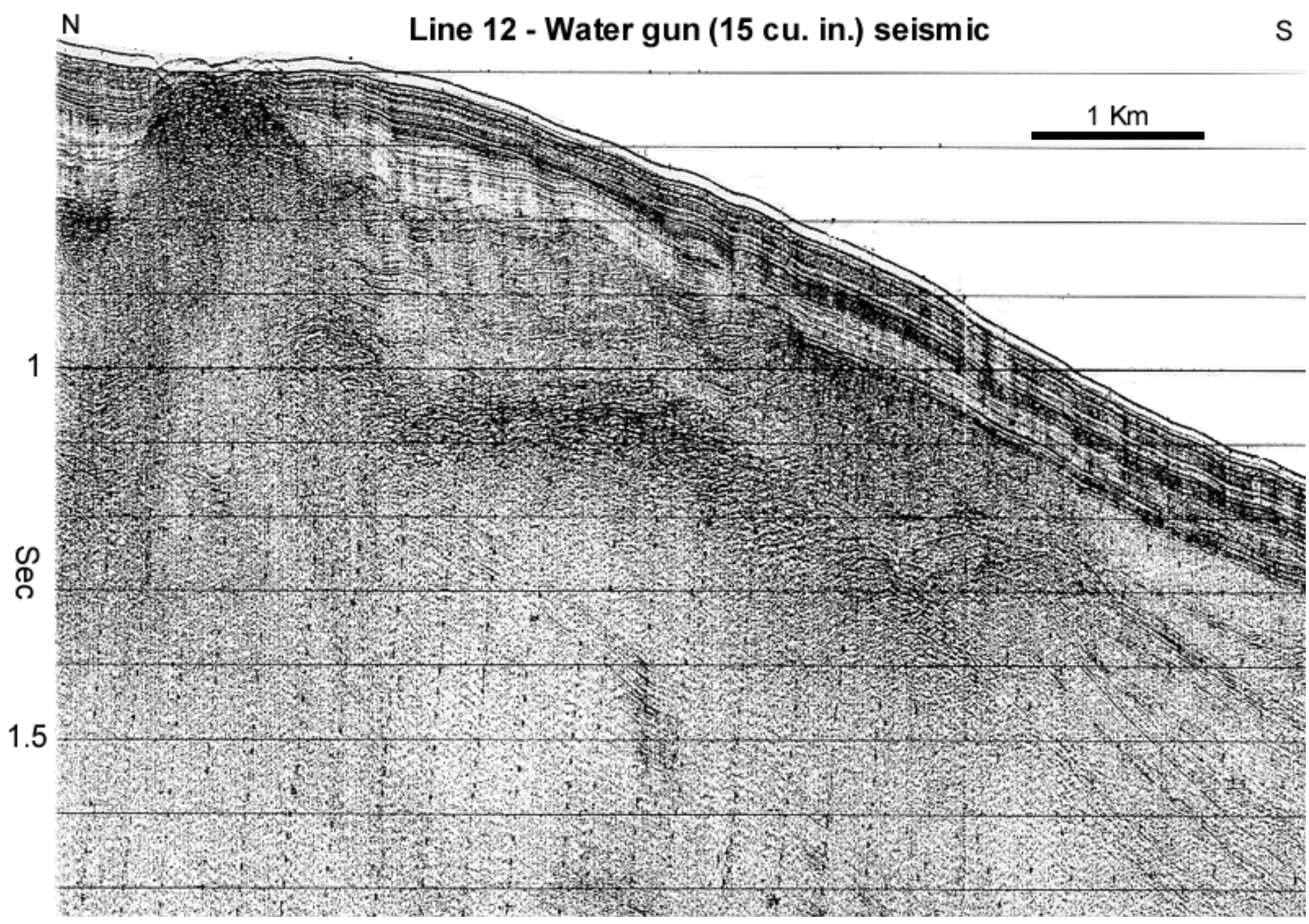

Figure 5. Example of water-gun seismic-reflection Line 12 recorded across the upper continental slope during cruise G1-99-GM. A well-stratified unit covers sediments with acoustic-wipeout and high-amplitude zones, broadly associated with deep-seated diapir and fault structures. Shallow water flows are reported from the area (0.6-0.9 sec water depths) where a chaotic high-amplitude zone (gases?) occurs and where shallow faults that displace uppermost strata sole out. Hydrates are stable near the sea-floor at these depths, depending on gas compositions and bottom-water temperatures. Here, as elsewhere, subsurface faulting and intrastratal deformation that displaces the sea floor seems enhanced by gas/fluid flows, which may in places be controlled at shallow depths partly by features of the gas hydrate stability zone. 


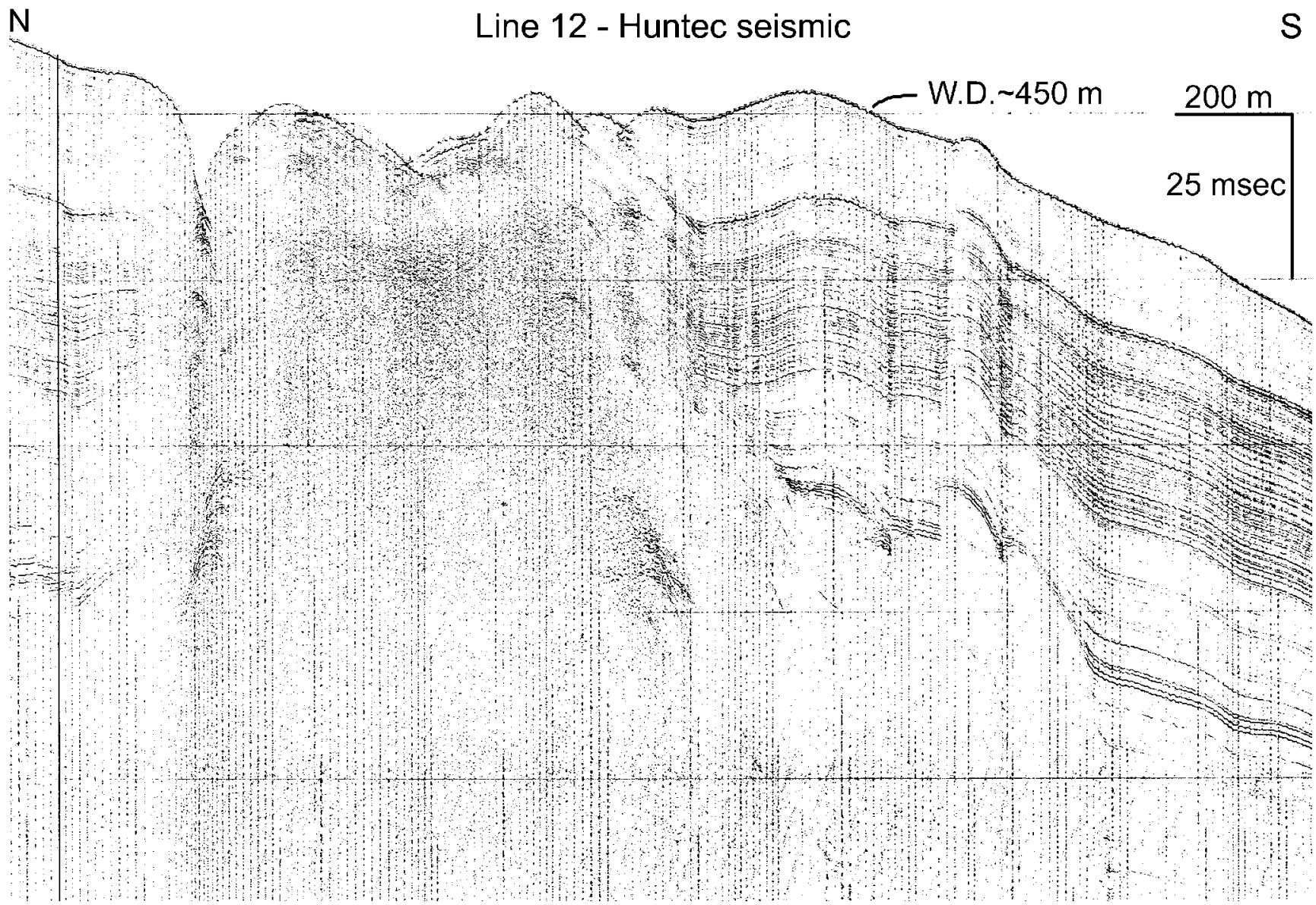

Figure 6. Example of Huntec seismic-reflection Line 12 recorded across a large diapir structure (i.e., Figure 5) beneath the upper continental slope during cruise G1-99-GM. Numerous nearvertical faults are seen with some sea-floor scarps and mound-like features. Localized highamplitude chaotic reflections may be from gassy and/or disrupted strata. The area is marked by high sea-floor backscatter. 
derived from adjacent buried beds. Where shallow strata are within the estimated gas hydrate stability zone, large amplitude variability occurs locally within chaotic subsurface layers sandwiched between well-stratified units. Some of these occurrences are in areas where shallow-flows have been encountered in drill holes. In general, the large-amplitude variability in the shallow subsurface appears stratigraphically and to a lesser extent water-depth controlled, but the specific explanations require further analysis and acquisition of detailed geologic core data.

In side-scan data, the sea-floor commonly has high backscatter over the crests of salt structures and along fault zones where gas hydrates, authigenic carbonates, and biologic communities have been observed. High backscatter is also found on steep slopes and in basin floors associated with mass-wasting deposits. Backscatter is generally low over slope and basin areas that are dominated by well stratified and undisrupted strata.

\section{Possible links}

The new side-scan and high-resolution seismic-reflection data provide additional evidence, to the 1998 cruise data (Cooper et al., 1999), to suggest that gas hydrates are more widespread at the sea floor, and possibly below, than currently known from other studies (e.g., Roberts, 1995). Features suggestive of the gas hydrates occur near many of the extensive sea-floor failures evident in the NOAA swath bathymetry data across the continental slope (Figure 2) failures that are in turn related on a regional scale to underlying salt movements and development of the numerous basins and rises. On a local scale, structures possibly associated with sea-floor gas hydrate deposits are complex and varied (e.g. diapirs, circular fault systems, en echelon headwall scarps, etc.), and in many cases are also associated with nearby mass-wasting features. Tracklines were run across many such sea-floor and buried failures (e.g., slumps, slides, flows) to determine the extent to which they may be affected or caused by shallow gas-hydrate-related processes.

In swath bathymetry data, sea-floor failures range widely in displacement and style of failure. In shipboard seismic-reflection profiles, the displacements commonly increase at depth implying prior and continuing deformation to the present time. Lateral intrastratal deformation within shallow and thin layers along which potentially large areas of the sea-floor have moved (or be moving?) is also observed. These deformed layers can be traced in places upslope to sea-floor failures (e.g., Figure 4). In other places, the widespread lateral deformation is confined to a thin zone sandwiched between flat lying strata. The association of such features, some of which may be actively moving and deforming the sea floor, with possible shallow-subsurface gas deposits (e.g., Figure 5) at depths where gas hydrates are stable, suggests that such failures and gas hydrates are linked. Further assessment of the potential role of gases and gas hydrates in facilitating slope and sea-floor failures awaits data processing and analysis.

\section{Summary}

High resolution seismic-reflection profiles and side-scan sonar images were recorded in April 1999 across the Green Canyon and Garden Banks regions of the Gulf of Mexico to study the 
distribution of potential gas hydrates, and to determine the link, if any, between gas hydrates and known slope and sea-floor failures. Shipboard records show evidence of widespread shallow gas and subsurface deformation within or directly below the estimated gas hydrate stability zone. These data, after futher processing, should more clearly illustrate the relationship between migrating gases/fluids, gas hydrates and slope and sea-floor failure features.

\section{Acknowledgments}

Funding for the cruise was from the USGS Coastal and Marine Geology Program and a grant from the Department of Energy. We gratefully acknowlege the efforts of the ships's crew, the USGS science-support staff, and the Geoforce technician to ensure a safe and productive cruise. The Minerals Management Service, New Orleans, provided valued assistance accessing data used in site selections. We thank the University of Mississippi for the use of their 15 cu.in. water gun. We appreciate the help of Rebecca Cooper in compiling data and preparing maps, and Michael Hamer and Carolyn Degnan in preparation of swath-bathymetry maps. 


\section{References}

Anderson, A.L., Sloan, E.D., and J.M. Brooks, 1992, Gas hydrate recoveries in the Gulf of Mexico: What is the shallow water depth limit for hydrate occurrence?, Proceedings 24 th Offshore Technology Conference (1992), Paper 6853, 381-385.

Cooper, A.K., Hart, P., and I. Pecher, 1999, Cruise Report for aa seismic investigation of gas hydrates in the Mississippi Canyon region, northern Gulf of Mexico -- Cruise M1-98-GM, U.S. Geological Survey Open-file report 98-506, 25 p.

Foster, D.S., Twichell, D.C., Danforth, W.W., Irwin, B.J., Nichols, D.R., and O'Brien, T.F., 19XX, Archive of Datasonics SIS-1000 chirp subbottom data collected during USGS cruise GYRE 99002, Gulf of Mexico, 9-22 April, 1999: USGS Open-File Report 99-XXX, 3 CDROMs.

Goodwin, R.H., and D.B. Prior, 1989, Geometry and depositional sequences of the Mississippi Canyon, Gulf of Mexico, Journal of Sedimentary Petrology, 59/2, 318-329.

Kvenvolden, K. A., 1993, Gas hydrates -- geological perspective and global change, Rev. Geophys, 31(2), 173-187.

Roberts, H. H., 1995, High-resolution surficial geology of the Louisiana middle-to-upper continental slope, Gulf Coast Association of Geological Societies Transactions, v. XLV, p. 503-508.

Weimer, P. et al., 1998, Sequence stratigraphy of Pliocene and Pleistocene turbidite systems, northern Green Canyon and Ewing Bank (offshore Louisiana), northern Gulf of Mexico, AAPG Bulletin, 82/5B, 918-960. 


\section{Figure Captions}

Figure 1. Index maps showing (A) shaded-relief bathymetry in the northern Gulf of Mexico, with box around the Green Canyon and Garden Banks study area, and (B) bathymetric contours at $200 \mathrm{~m}$ intervals, and locations of seismic-reflection tracklines for cruise G1-99-GM. Sidescan and chirp seismic-reflection data were collected only in detailed surveys in the eastern part of the area (i.e., Green Canyon area).

Figure 2. Shaded-relief map of NOAA swath bathymetry data in the study area. Locations of seismic-reflection tracklines for cruise G1-99-GM are also shown. The irregular bathymetry of basins, rises and sea-floor displacements result principally from movements of deep-seated salt.

Figure 3. Example of side-scan data recorded on cruise G1-99-GM in the Green Canyon area, shown sea-floor backscatter information. Light colored areas are high backscatter (hard ground) and dark areas are low backscatter (soft ground). High backscatter is associated with sea-floor fault and diapir systems where gases, fluids, sediment rise to the seafloor resulting in likely diagenetic deposits (e.g., authigenic carbonates), gas hydrates (where stable), brines, and coarse or disrupted sediments. Blocky lines show approximate water depths. Solid white line is location of seismicreflection Line 15 in Figure 4.

Figure 4. Examples of seismic-reflection Line 15 recorded across a fault zone during cruise G1-99GM. A. Chirp seismic-reflection, and B. Water gun seismic-reflection. Chirp seismic-reflection show a likely mud volcano adjacent to the fault zone where near-surface seismic-reflection amplitudes are high and the seafloor is disrupted. Water gun data illustrate that the high-amplitude reflections extend downward in two zones, one that projects steeply (i.e., the master fault with likely gas/fluid) and another that projects laterally along apparent stratigraphy (i.e., a potential gas/fluid charged stratal unit). The fault zone has high backscatter at the sea floor (Figure 3), and is an area of likely upward migrating gases, fluids, and mobilized sediment, with contributions from the two subsurface high-amplitude zones.

Figure 5. Example of water-gun seismic-reflection Line 12 recorded across the upper continental slope during cruise G1-99-GM. A well-stratified unit covers sediments with acoustic-wipeout and high-amplitude zones, broadly associated with deep-seated diapir and fault structures. Shallow water flows are reported from the area (0.6-0.9 sec water depths) where a chaotic high-amplitude zone (gases?) occurs and where shallow faults that displace uppermost strata sole out. Hydrates are stable near the sea-floor at these depths, depending on gas compositions and bottom-water temperatures. Here, as elsewhere, subsurface faulting and intrastratal deformation that displaces the sea floor seems enhanced by gas/fluid flows, which may in places be controlled at shallow depths partly by features of the gas hydrate stability zone.

Figure 6. Example of Huntec seismic-reflection Line 12 recorded across a large diapir structure (i.e., Figure 5) beneath the upper continental slope during cruise G1-99-GM. Numerous near-vertical faults are seen with some sea-floor scarps and mound-like features. Localized high-amplitude chaotic reflections may be from gassy and/or disrupted strata. The area is marked by high sea-floor backscatter. 


\section{Appendix A: Trackline specifications for cruise G1-99-GM}

\begin{tabular}{|c|c|c|c|c|c|}
\hline Line \# & $\begin{array}{c}\text { Julian } \\
\text { Day }\end{array}$ & $\begin{array}{l}\text { Start } \\
\text { Time }\end{array}$ & $\begin{array}{l}\text { End } \\
\text { Time }\end{array}$ & $\begin{array}{c}\text { Line } \\
\text { Direction }\end{array}$ & $\begin{array}{l}\text { Data } \\
\text { Types }\end{array}$ \\
\hline test1 & 100 & 1751 & 1825 & SW-NE & $\mathrm{mcs}, \mathrm{ss}, \mathrm{c}$ \\
\hline test2 & 100 & 1828 & 2236 & SW-NE & $\mathrm{mcs}, \mathrm{ss}, \mathrm{c}$ \\
\hline 1 & 100 & 2254 & 0203 & $\mathrm{~N}-\mathrm{S}$ & $\mathrm{mcs}, \mathrm{sS}, \mathrm{c}$ \\
\hline 2 & 101 & 0228 & 0447 & SE-NW & $\mathrm{mcs}, \mathrm{ss}, \mathrm{c}$ \\
\hline 3 & 101 & 0451 & 0700 & $\mathrm{~N}-\mathrm{S}$ & $\mathrm{mcs}, \mathrm{ss}, \mathrm{c}$ \\
\hline 4 & 101 & 0701 & 0808 & $\mathrm{~S}-\mathrm{N}$ & $\mathrm{mcs}, \mathrm{sS}, \mathrm{c}$ \\
\hline 5 & 101 & 0809 & 1131 & E-W & $\mathrm{mcs}, \mathrm{ss}, \mathrm{c}$ \\
\hline 6 & 101 & 1218 & 1619 & NE-SW & mcs, h \\
\hline 7 & 101 & 1630 & 1731 & E-W & mcs, h \\
\hline 8 & 101 & 1732 & 2050 & SE-NW & mcs, h \\
\hline 9 & 101 & 2103 & 2231 & W-E & mcs, h \\
\hline 10 & 101 & 2231 & 2338 & NE-SW & $\mathrm{mcs}, \mathrm{h}$ \\
\hline 11 & 101 & 2346 & 0013 & SE-NW & mcs, h \\
\hline 12 & 102 & 0137 & 0451 & $\mathrm{~N}-\mathrm{S}$ & mcs, $\mathrm{h}$ \\
\hline 13 & 102 & 0458 & 0634 & SE-NW & mcs, $\mathrm{h}$ \\
\hline 14 & 102 & 0635 & 0832 & $\mathrm{~S}-\mathrm{N}$ & $\mathrm{mcs}, \mathrm{h}$ \\
\hline 15 & 102 & 0902 & 1343 & W-E & $\mathrm{mcs}, \mathrm{ss}, \mathrm{c}$ \\
\hline 16 & 102 & 1355 & 1733 & E-W & $\mathrm{mcs}, \mathrm{ss}, \mathrm{c}$ \\
\hline 17 & 102 & 1740 & 2309 & W-E & $\mathrm{mcs}, \mathrm{ss}, \mathrm{c}$ \\
\hline 18 & 102 & 2312 & 0228 & E-W & $\mathrm{mcs}, \mathrm{ss}, \mathrm{c}$ \\
\hline 19 & 103 & 0308 & 0703 & W-E & $\mathrm{mcs}, \mathrm{ss}, \mathrm{c}$ \\
\hline 20 & 103 & 0713 & 1114 & E-W & $\mathrm{mcs}, \mathrm{sS}, \mathrm{c}$ \\
\hline 21 & 103 & 1123 & 1522 & W-E & $\mathrm{mcs}, \mathrm{ss}, \mathrm{c}$ \\
\hline 22 & 103 & 1534 & 1905 & E-W & $\mathrm{mcs}, \mathrm{sS}, \mathrm{c}$ \\
\hline 23 & 103 & 1921 & 2328 & W-E & $\mathrm{mcs}, \mathrm{ss}, \mathrm{c}$ \\
\hline 24 & 104 & 0021 & 0105 & E-W & $\mathrm{mcs}, \mathrm{ss}, \mathrm{c}$ \\
\hline 25 & 104 & 0325 & 0754 & W-E & $\mathrm{mcs}, \mathrm{ss}, \mathrm{c}$ \\
\hline 26 & 104 & 0810 & 1238 & E-W & $\mathrm{mcs}, \mathrm{sS}, \mathrm{c}$ \\
\hline 27 & 104 & 1252 & 1540 & W-E & $\mathrm{mcs}, \mathrm{ss}, \mathrm{c}$ \\
\hline 28 & 106 & 2112 & 2344 & $\mathrm{~S}-\mathrm{N}$ & mcs, $\mathrm{h}$ \\
\hline 29 & 107 & 0003 & 0024 & E-W & $\mathrm{mcs}, \mathrm{h}$ \\
\hline 30 & no line & - & - & - & - \\
\hline 31 & 107 & 0241 & 0502 & $\mathrm{~N}-\mathrm{S}$ & $\mathrm{mcs}, \mathrm{h}$ \\
\hline 32 & 107 & 0508 & 0819 & SE-NW & mcs, $\mathrm{h}$ \\
\hline 33 & no line & - & - & - & - \\
\hline 34 & 107 & 0827 & 1545 & NE-SW & $\mathrm{mcs}, \mathrm{h}$ \\
\hline 35 & 107 & 1548 & 1653 & E-W & mcs, h \\
\hline 36 & 107 & 1654 & 2037 & NW-SE-NW & mcs, $\mathrm{h}$ \\
\hline 37 & 107 & 2050 & 2333 & SE-NW & $\mathrm{mcs}, \mathrm{h}$ \\
\hline 38 & 107 & 2348 & 0018 & NE-SW & mcs, $\mathrm{h}$ \\
\hline
\end{tabular}




\begin{tabular}{|c|c|c|c|c|c|}
\hline 39 & 108 & 0110 & 0146 & NW-SE & mcs, h \\
\hline 40 & 108 & 0158 & 0423 & NW-SE & mcs, h \\
\hline 141 & 108 & 0456 & 0914 & NE-SW & mcs, h \\
\hline 143 & 108 & 0914 & 1010 & SW-NE & mcs, h \\
\hline 144 & 108 & 1317 & 1359 & SW-NE & mcs, h \\
\hline 41 & 108 & 1408 & 2143 & SW-NE & mcs, h \\
\hline 42 & 108 & 2143 & 0247 & NW-SE & mcs, h \\
\hline 43 & 109 & 0251 & 0743 & NE-SW & $\mathrm{mcs}, \mathrm{h}$ \\
\hline 44 & 109 & 0753 & 1058 & SE-NW & mcs, h \\
\hline 45 & 109 & 1058 & 1351 & SW-NE & mcs, h \\
\hline 46 & 109 & 1352 & 1450 & SE-NW & mcs, h \\
\hline 47 & 109 & 1457 & 1741 & NE-SW & mcs, h \\
\hline 48 & 109 & 1744 & 2026 & NW-SE & mcs, h \\
\hline 49 & 109 & 2037 & 2109 & SW-NE & mcs, h \\
\hline 50 & 109 & 2109 & 2222 & SE-NW & mcs, h \\
\hline 51 & 109 & 2223 & 0544 & NE-SW & mcs, h \\
\hline 151 & 110 & 0611 & 0649 & NE-SW & mcs, h \\
\hline 152 & 110 & 0649 & 0730 & SW-NE & mcs, h \\
\hline 52 & 110 & 0733 & 1126 & SW-NE & mcs, $h$ \\
\hline 53 & 110 & 1136 & 1520 & SE-NW & $\mathrm{mcs}, \mathrm{h}$ \\
\hline 153 & 110 & 1558 & 1944 & SE-NW & mcs, h \\
\hline 54 & 110 & 1945 & 2143 & NE-SW & mcs, h \\
\hline 55 & 110 & 2147 & 2341 & W-E & mcs, h \\
\hline 56 & 110 & 2342 & 0030 & S-N & mcs, h \\
\hline 156 & 111 & 0121 & 0236 & S-N & mcs, h \\
\hline 57 & 111 & 0238 & 0502 & W-E & mcs, h \\
\hline 58 & 111 & 0503 & 0551 & NW-SE & mcs, h \\
\hline 59 & 111 & 0559 & 0944 & SE-NW & mcs, h \\
\hline 60 & 111 & 0950 & 1318 & NW-SE & mcs, h \\
\hline 61 & 111 & 1319 & 1425 & SW-NE & mcs, h \\
\hline
\end{tabular}

$\mathrm{c}=$ chirp seismic-reflection $(4-10 \mathrm{kHz}$ deep tow system)

$\mathrm{h}=$ Huntec boomer (ddp-tow high resolution seismic-reflection data)

mcs $=$ multichannel seismic-reflection with $15 \mathrm{cu}$.in. water gun

ss $=$ side-scan sonar data $(100 \mathrm{kHz}$ deep tow system $)$ 